\title{
"The impact of the European Banking Union's Single Supervisory Mechanism on corporate governance practices in European banks"
}

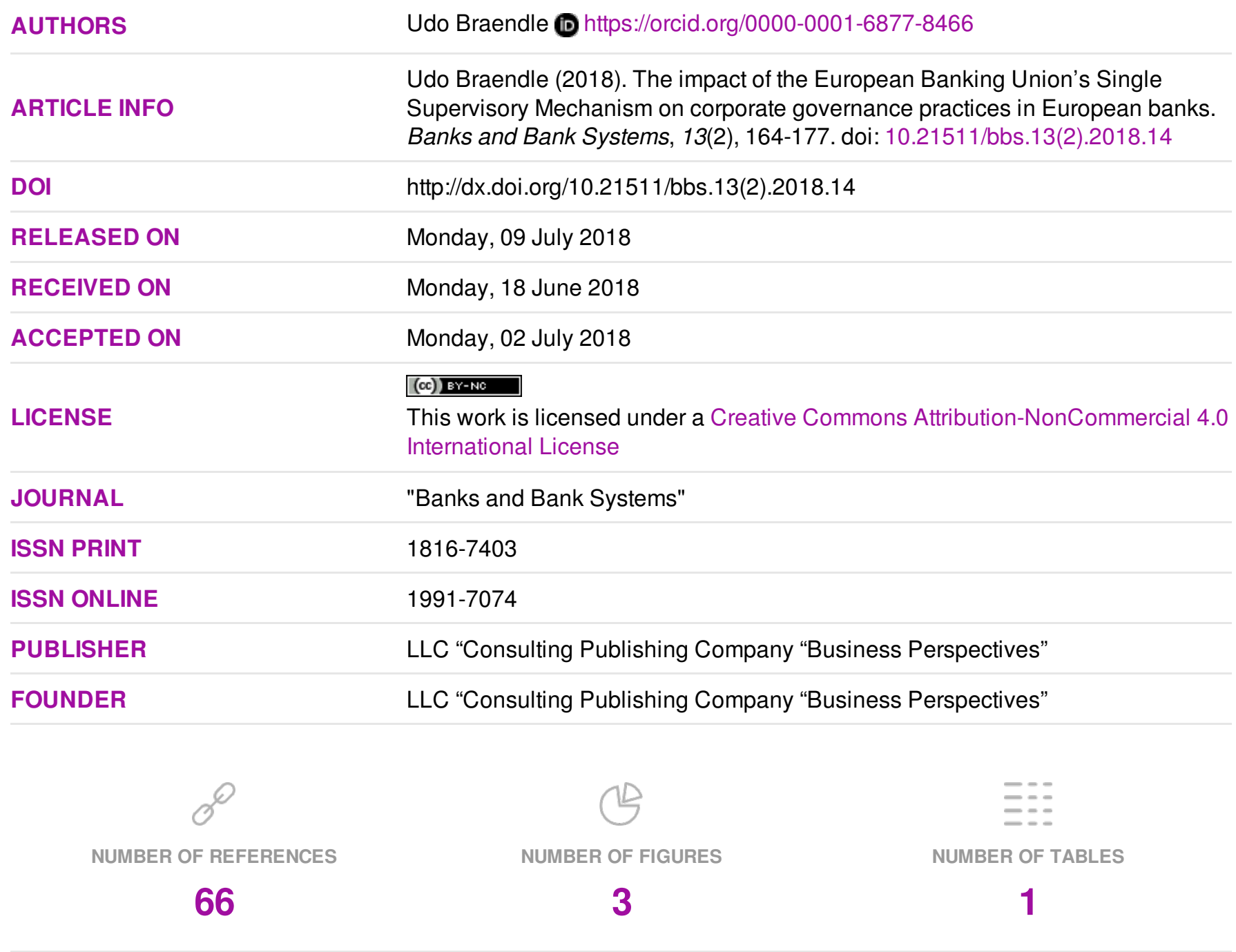

(c) The author(s) 2023. This publication is an open access article. 


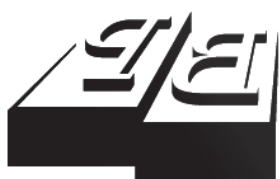

BUSINESS PERSPECTIVES

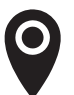

LLC "CPC "Business Perspectives" Hryhorii Skovoroda lane, 10, Sumy, 40022, Ukraine

www.businessperspectives.org

Received on: $18^{\text {th }}$ of June, 2018 Accepted on: $2^{\text {nd }}$ of July, 2018

(c) Udo Braendle, 2018

Udo Braendle, Dr., Associate Professor, Chair, General Business and Management Department, American University in Dubai, United Arab Emirates

\section{(ㄷ)(1) $(8$}

This is an Open Access article, distributed under the terms of the Creative Commons Attribution-NonCommercial 4.0 International license, which permits re-use, distribution, and reproduction, provided the materials aren't used for commercial purposes and the original work is properly cited.
Udo Braendle (United Arab Emirates)

\section{THE IMPACT OF THE EUROPEAN BANKING UNION'S SINGLE SUPERVISORY MECHANISM ON CORPORATE GOVERNANCE PRACTICES IN EUROPEAN BANKS}

\begin{abstract}
Weak corporate governance in financial institutions has been a contributing factor of the financial crisis. The topic has, therefore, become the key priorities of banking supervision, because one of the takeaways was that. The article gives an overview about the newly established European Banking Union and about its structure focusing on the first pillar, the Single Supervisory Mechanism (SSM). In a second step, the focus is laid on the recent regulatory changes regarding corporate governance, the related supervisory practice and implications for European banks. Overall, the conducted changes in the regulatory framework, especially regarding corporate governance, seem to meet the objective of ensuring safety and soundness of the European banking system. Room for improvement is found regarding proportionality and transparency of the supervisory practices as well as its influence on banks' profitability.
\end{abstract}

Keywords

JEL Classification

European Banking Union, Single Supervisory Mechanism, corporate governance, regulation

G21, G28, G38

\section{INTRODUCTION}

The recent financial crisis showed that a deregulated financial sector can be dangerous for the world economy. So, politicians and regulatory authorities around the world took appropriate steps to increase regulation. The member states of the European Union have chosen a very centralized approach by establishing the European Banking Union. In addition to the failing of credit institutions, the financial crisis revealed severe shortcomings in corporate governance, e.g. in risk management and executive remuneration, especially in financial services companies. This paper combines the two aspects, stricter regulation and improved corporate governance, in order to assess, on the one hand, the impact of the new legal framework and the regulatory set-up for European banks in general and, on the other hand, the changes, consequences and next steps with specific regard to corporate governance practice in detail. The topic is of high practical relevance, because these changes affect all banks, from multinational corporations to small regional banks.

The European Banking Union comprises three pillars. The first pillar relates to banking supervision, the second to resolution and the third to deposit insurance. The objective of this paper is to determine what has changed with respect to corporate governance in European banks after the European Central Bank (ECB) established the Banking Union and has implemented the first part - the Single Supervisory Mechanism (SSM) - and what are the consequences for financial institutions. Much attention is given to the main tool of ongoing supervision, the Supervisory Review and Evaluation Process (SREP). 


\section{THE EUROPEAN BANKING UNION}

The practical achievements and the current set-up of European banking system is influenced heavily by regulation theory. Ogus (2009) states that regulation is "designed to induce individuals and firms to outcomes which they would not voluntarily reach. Regulation is largely enforced by public officials and compliance is aided by the threat or imposition of some sanction". Dragomir (2010) analyzes regulation theory in the context of European prudential banking regulation and supervision and starts by referring to Majone (1996) who differentiates between the terms economic and social regulation. Economic regulation means all regulatory activities which have the purpose to limit market powers. Whereas social regulation refers to consumer protection and safety. Traditionally, economic banking regulation was more common in the US than in Europe. Regulators were afraid that banks may become too powerful in terms of their economic strength, especially following the deregulation phase in the 1980s.

Generally, regulation in all industries is imposed because of market failures like externalities, market power or information asymmetries (Santos, 2000). In the past, there was not always general agreement among practitioners and theorists whether banks need to be regulated at all (Santos, 2000), but the recent financial crisis is the best example why regulation is absolutely necessary. Santos (2000) provides two arguments for the existence of banking regulation: systemic risk and the protection of depositors' interests. Freixas and Santomero (2003) further differentiate between three types of market failure. The first reason is monetary liquidity costs. Central banks have the responsibility to assure that enough liquidity is provided in the monetary system. Hence, they have the duty to oversee the banks' assets and liabilities management. Costs of bank failure which relates to the systemic risk factor is stated as the second type of market failure. Efficiency in the financial sector depends on confidence in the financial institutes and transparency of information to all market participants. When it comes to regulation itself, higher levels of efficiency are achieved by cost-benefit analysis for each new regulation.
Also banking regulation differs from other sectors from the perspective of their goals and how they make use of instruments in order to achieve their targets. Contrary e.g. to the energy market, regulation in the financial sector is more focused on safety of the system and not so much on price (Cao, 2014). The most important instruments of banking regulation are capital requirements, deposit insurance, disclosure requirements and bank examination (Mishkin, 2001). Bank examination refers to the duty of the regulator to check whether the respective entities comply with the regulatory framework and to impose actions in case of non-compliance. Banking supervision goes one step further by conducting qualitative and quantitative analysis regarding the soundness of the bank management. Mishkin (2001) defines these two different tasks as "regulatory" and "supervisory" approach.

Davis and Obasi (2009) elaborate on different aspects which have to be considered when designing efficient banking supervision. First, it has to be decided who shall be the supervisory authority: the central bank or another agency. Central banks have the advantage that they have most of the important information at hand and that they are used to adopt a macroeconomic and systemic view. But, the disadvantage is that the central banks may be exposed to a conflict of interest because of their different duties. A compromise is a set-up with the central bank being responsible for macro-oversight and another agency undertaking all other duties of supervision. However, Pichet (2014) shares the opinion that macro-regulation and micro-supervision have to be much better aligned, which he thinks would be one solution that could have reduced the extent of the financial crisis. A further aspect regarding the design of supervision concerns independency. It is important that the entrusted bank supervisors are independent from politicians during their appointment phase and form the supervised entities at any time (Davis \& Obasi, 2009). The assigned powers to supervisory authorities are a further mentioned integral part of the supervisory framework. It can be observed that regulatory convergence became more important with the increase of cross border banking (Davis \& Obasi, 2009). Penikas (2015) analyzes the past 40 years of Basel Committee of Banking Supervision (BCBS) and the related re- 
gulatory and supervisory framework and its development, and outlines that the number of publicized pages concerning BCBS banking regulation increased significantly over the period from 1974 to 2014 and finds in a much generalized way correlation between the number of pages published by the BCBS and the trend of economic activity indicated by S\&P 500 .

The banking sector is highly regulated and supervised in comparison to other sectors, as the energy market, where the trend went in the direction of more liberalization (Eken et al., 2013). The authors state that the relation between banks and individuals is a principle-agent problem with strong influence of asymmetric information. The recent financial crisis is an expressive example for the systemic risk theme. It has been shown that a shock in one location or asset class may have tremendous implications for markets and institutions worldwide (Cerutti et al., 2012). Bullard et al. (2009) argue that financial companies are more exposed to systemic risk than non-financial firms, caused by the high interconnections of banks, high leverage, and because banks tend to use short-term debt to finance long-term assets. This was more the case in times of weak liquidity management, which was broadly improved through the last five years. The answer to minimize or decrease systemic risk of banks is stricter regulations. However, a globalized world with interconnected markets and a large number of financial institutes that are 'toobig-to-fail' requires macroprudential regulation and supervision (Galati \& Moessner, 2011). In the European Union, the solution for facing the risks of interdependencies - learning from the failures in the recent financial crisis - was to create the European Banking Union (EC, 2014). Beck (2015) names several reasons for the necessity of a centralized European Banking Union, for example that in a decentralized system local regulators' priority lies on the stability of the national stability interests neglecting the interdependencies and that governance structures of the national authorities are enhanced (Hodson \& Quaglia, 2009). The US set-up of banking regulation and supervision differed from the setup in the EU at that time. In general, the crisis hit the US and the EU in a similar way. However, because of different regulatory set-up the US reacted much faster to the deficiencies, since it was possible to delay the implementation of financial reforms due to sovereign layers in the EU (Eubanks, 2010). Also Breuss (2013) indicates that the difference in how the two areas cope with the challenges was that the US already had a well-functioning monetary union in comparing two economic entities with almost identical statistics and effects during the crisis - Ireland and Nevada. In both entities, the banks suffered during the crisis with huge losses and also many banks became bankrupt. However, the big difference was that in Ireland the banks' failure resulted in a financial crisis for the country, whereas in Nevada the problems were taken on a federal level, because the US is and already was a banking union at that time, and the Federal Deposit and Insurance Corporation (FDIC) stepped in and managed the treatment of failed banks without using taxpayers' help.

The European Central Bank (ECB) is the most important authority for the operational execution in the European Banking Union. Within the SSM, the ECB is, together with National Competent Authorities (NCAs) (ECB, 2014), responsible for a major part of the supervisory tasks. NCAs are the responsible authorities, usually the National Central Banks (NCBs) in all member states of the SSM.

Besides the SSM, the European Banking Union comprises of a second pillar, the Single Resolution Mechanism (SRM). The authority responsible for the SRM is the Single Resolution Board (SRB) together with the National Resolution Authorities (NRAs) aiming at being prepared for and conducting resolution of failing banks (SRB, 2015).

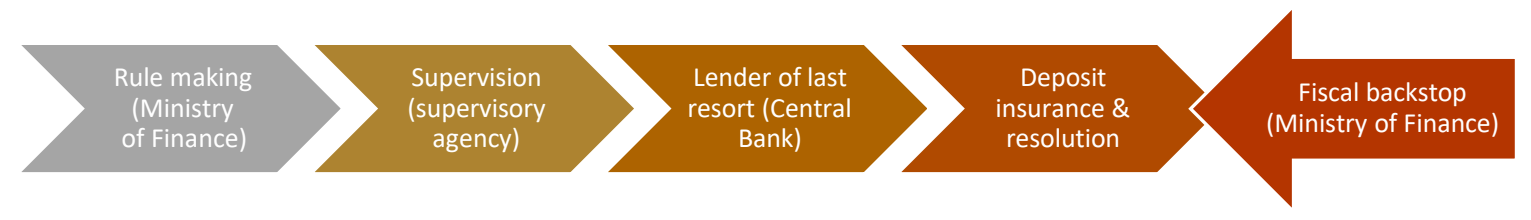

Figure 1. Governance framework of the European Banking Union 


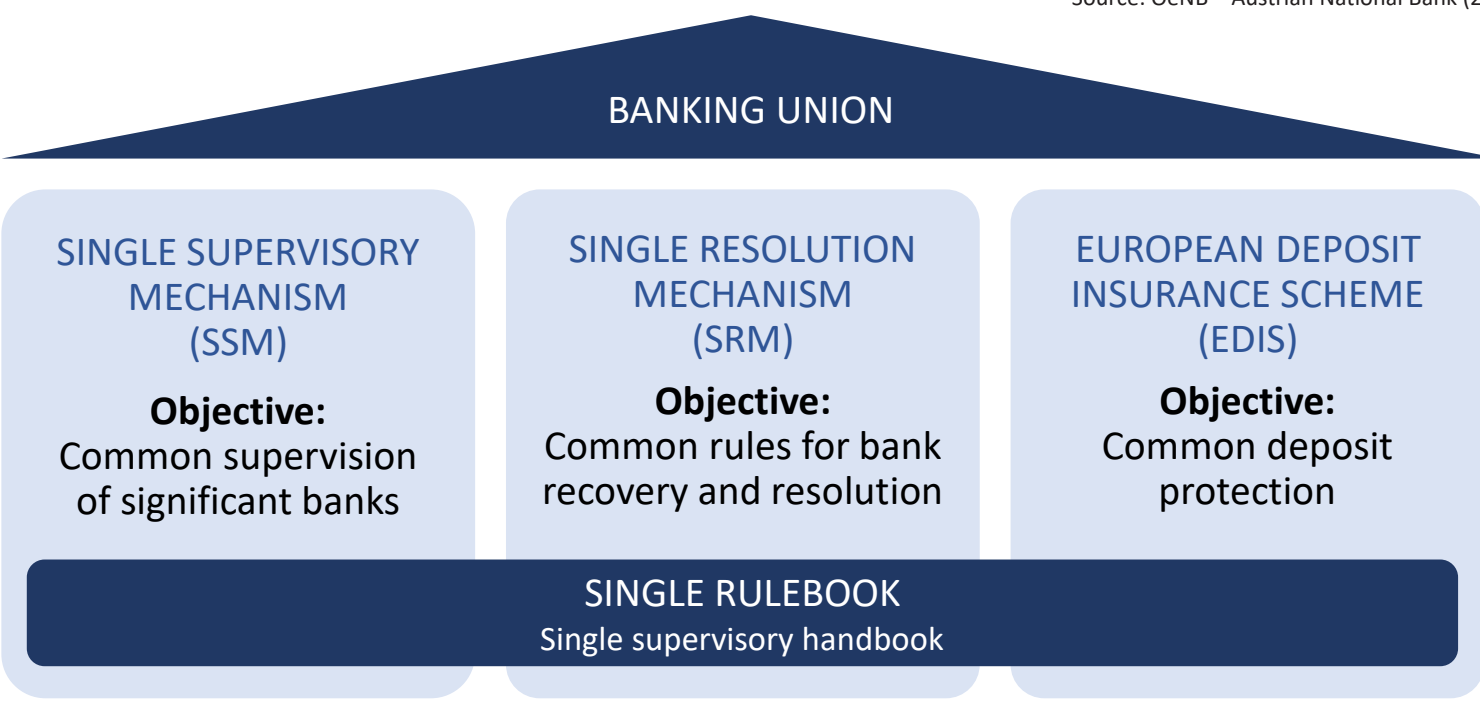

Figure 2. The structure of the European Banking Union

The third part of the European banking framework is the European Stability Mechanism as a tool for recapitalization. Schoenmaker (2015) summarizes, as depicted in Figure 1, the governance framework in the European Banking Union, from policy-making over supervision, lender of last resort and resolution to fiscal backstop.

Summed up, the three pillars together with the Single Rulebook (supervisory handbook) build the fundament of the banking union (see Figure 2).

\section{STRICTER REGULATION}

Stricter regulation in the form of the Single Supervisory Mechanism became operational on November 4, 2016. The SSM is responsible for the oversight of all banks in the euro area. The types of banks are credit institutions, financial holding companies, mixed financial holding companies and branches of credit institutions established in non-participating member states. Also, EU countries with currencies other than the euro can join to participate in the European Banking Union and, therefore, also in the SSM by close cooperation agreements (Deutsche Bundesbank, 2016). Up to now, not a single EU country that is not part of the Eurozone decided to opt in. The potential benefits of joining the SSM are increased European integration and attraction of foreign investors due to better coordination (Kosior \& Rubaszek, 2015).
Within the scope of the SSM banks it is differentiated between Significant Institutions (SI) and Less Significant Institutions (LSI). Credit institutions in the member areas are regularly assessed whether they fall under the classification significant or not. The criteria for the type of classification are determined in Art. 6 para. 4 SSMR as size of the institution, importance for the economy and significance of cross-border activities.

As of January 1,2017, 125 banking groups, which are accounting together for almost $85 \%$ of total banking assets in the euro area, are classified as significant and are, therefore, directly supervised by the ECB (ECB - Banking Supervision, 2017a). These groups comprise in total about 1,200 supervised entities. All of these entities are subject to direct supervision because it is stated in the SSMR Art. 6 para. 4 that applies at the highest consolidated level, which means that subsidiaries of significant institutions are also directly supervised (Tröger, 2013). In contrast, 3,500 entities are specified as LSIs and are still supervised by the local NCAs (ECB, 2014). However, the oversight function of the ECB that provides coordination and guidance developed and still develops the supervisory approach also in the NCAs (Tröger, 2013). The ECB gives the NCAs direction in terms of regulations, guidelines or general instructions and is entitled to step in and undertake direct supervision for one or more credit institutions by exerting supervisory power through requests for information, investigations and on-site inspections (SSMR, Art. 6 para. 6). 
For the day-to-day tasks of direct supervision, the ECB installed Joint Supervisory Teams (JST) for each significant institution, which are assembled with supervisors from ECB and NCAs from states where the credit institution, its subsidiaries or significant cross-border branches of a given banking group are established. Each JST comprises three levels. On the first level the JST coordinator operates, who is the chair of the JST, is usually not from the country where the supervised entity is established and is appointed for a period from three to five years. The second level, the core JST, is composed of sub-coordinators from NCAs who take responsibility for certain specified areas of supervision. The core team can be supported by expertise divisions from ECB and assists the JST coordinators. The basis of the JSTs is made by teams of experts from both ECB and NCAs, which can be consulted according to the actual scope and priorities of JST's supervision. The composition of JSTs varies depending on the nature, complexity, scale, and business model as well as risk profile of the supervised credit institution (ECB, 2014).

The elements of supervision in the SSM are multilayered. The banks in the participating member states are stressed, controlled and evaluated from many perspectives and with various instruments. Starting with a stress test and Asset Quality Review (AQR), the supervisors established practices such as the Supervisory Review and Evaluation Process, on-site inspections in specific risk areas and model investigations. Furthermore, the ECB is responsible for granting authorization of credit institutions and taking fit and proper decisions by assessing the suitability of the management body of significant banks within the SSM.

A stress test was conducted before the ECB took over the operational supervisory responsibility for the banks in the euro area and stands for the starting point by evaluating the initial situation. A dedicated Asset Quality Review was performed as a second component together with the stress test in 2014 and both are summarized under the term Comprehensive Assessment. The AQR was undertaken by the ECB, whereas the stress test was carried out by EBA (De Groen \& Lannoo, 2014). The two parts of the Comprehensive Assessment have different samples of evaluated banks, however, the 93 most significant banks in the SSM at that time par- ticipated in both the ECB AQR and the EBA stress test (De Groen \& Lannoo, 2014). The AQR assessed the balance sheets of the banks as of December 31, 2013 and was focused on the proper specification of carrying values of the banks' assets (ECB, 2014). De Groen and Lannoo (2014) speak about a "test of the fairness and transparency of banks' balance sheets". While the AQR assessed the status quo of banks' healthiness and capital adequacy, the EBA stress test followed a forward looking approach by evaluating the resilience of the participating banks in certain macroeconomic scenarios (ECB, 2014). A further EBA stress test was conducted in 2016 with a reduced sample of 51 EU banks and included some slight adjustments in relation to the 2014 stress test (EBA, 2016). The results showing how the banks' capital is affected by macroeconomic shocks in a three-year time-horizon are fed into the SREP (EBA, 2016), which is the instrument for ongoing supervision. The ECB has mentioned positive development comparing the 2014 comprehensive assessment and the 2016 stress test, pointing out that the overall resilience of the European banking sector has improved (ECB, 2016).

Further important parts of JSTs supervisory activities are on-site inspections and model investigations. On-site inspections are inevitable in a strong banking supervision regime. The term "on-site" indicates that the investigation is conducted to a major extent in the premises of the bank that is subject to the inspection (Hafeman \& Randle, 2009). The legal basis of this duty is to be found in Article 12 of the SSM Regulation, where it is explicitly stated that the persons that were authorized by the ECB are allowed to enter the business premises of the inspected bank and can request any information which has to be provided. Furthermore, in Articles 143-146 of the SSM Framework Regulation it is written down that specific on-site teams have to be formed individually for each inspection. The inspection teams are composed of staff from ECB and NCAs and are led by a head of mission that is appointed by ECB also in cooperation with NCAs, but must not be a JST member to ensure independency (ECB - Banking Supervision, 2014). In 2015, about $95 \%$ of the deployed inspectors were NCA staff and just the remaining 5\% came from ECB's Centralized On-site Inspections Division (ECB - Banking Supervision, 2016a). Another vital benefit of the SSM is the diversity of banking supervisors, which allows views 
from outside and a mix of supervisory cultures. This aspect can be seen in a statistic from the SSM Annual Report 2016 (ECB - Banking Supervision, 2017b). In 2016, $40 \%$ of all on-site inspections were conducted in so called "mixed/cross border teams", meaning that one or more members of the inspection team are not nationals of the home country of the investigated bank. For the purpose of promoting this concept, a tool was installed where inspectors from NCAs can apply for participating in planned on-site inspections (ECB - Banking Supervision, 2017b). On the other side a negative implication of this concept could be that inspectors may not be familiar with the bank's peculiarities and local regulations, but this drawback can be eased through the other inspectors who are more familiar with the supervision of banks in the specific country. 185 inspections were conducted in total in 2016 and the inspection teams focused on the areas of credit risk, governance and operational risk.

To sum it up, and in order to display the full picture of the European Banking Union, even though not fully implemented, the other two pillars should be briefly mentioned. The second pillar of the European Banking Union is the Single Resolution Mechanism (SRM). The SRM is based on the legal framework set out in the Bank Recovery and Resolution Directive and the Single Resolution Mechanism Regulation (SRMR, Regulation 806/2014). The designated authority, the Single Resolution Board, is operational since January 1, 2015. After a transitional phase of one year, the SRM became fully operational as of January 1 , 2016 (SRB, 2016).

The SRB has to draft resolution plans for significant banks in the scope of the European Banking Union, assess the banks' resolvability and adopt resolution schemes when a credit institution is subject to severe financial problems and has to be either winded up under usual insolvency proceedings or use resolution. Apart from these main tasks the SRB also manages the Single Resolution Fund (SRF), which is the last resort built by contributions of the banking sector (SRB, 2016).

Breuss (2012) evaluates the costs and benefits of the Single Resolution Mechanism and concludes that the benefits are unequally distributed between the participating member states. Germany is stated as the biggest loser, whereas Spain and the Netherlands are titled as the main winners. This is the case because the 'bail-in' approach disadvantages countries with a sound banking system, which have to bail for countries with a poorer established system. However, Breuss, Roeger, and in't Veld (2015) find that if the European Banking Union would have been effective at the time of the financial crisis, GDP losses could have been reduced by $30-40 \%$ for periphery countries, i.e. the less developed, and by $10-40 \%$ for core countries depending on which resolution mechanism was in place.

The third pillar alongside supervision and resolution is the European Deposit Insurance Scheme (EDIS). The reason why this concept is not operational yet, is that it is highly controversially discussed and the implementation was blocked by some member states. Especially Germany has raised major concerns and rejection regarding the planned mechanism for deposit insurance. The current set-up with national deposit guarantee schemes is criticized as "promoting liquidity ring-fencing and market fragmentation in times of stress" (Wruuk, 2015). Furthermore, locally concentrated problems would have higher impact on each individual deposit guarantee scheme, which could be avoided more easily after the implementation of EDIS.

\section{IMPROVED CORPORATE GOVERNANCE?}

One of the major goals of the SSM is to increase the governance in European banks including the fitness and propriety of the management and key function holders. The following studies provide evidence for the assumption that weak corporate governance influenced the impact of the financial crisis and explain why the responsible people behind the creation of the Banking Union put their focus on the topic.

Kirkpatrick (2010) supports his analysis regarding the causes of the banking collapse by stating that "the financial crisis can be to an important extent attributed to failures and weaknesses in corporate governance arrangements". Incentives for excessive risk taking, insufficient accounting standards and regulatory requirements as well as weak re- 
muneration systems are mentioned as reasons for the failures. Dermine (2011) adds the underestimation of systemic risk by regulators to the list of reasons and highlights that also banking supervisors and regulators have to follow and implement strict corporate governance principles.

Several academic studies analyzed the impact of corporate governance practice in banks on the change of specific parameters during the financial crisis. In the following, the findings are summarized clustered into three Corporate Governance categories - risk management, boards and compensation.

\subsection{Risk management}

Risk governance - corporate governance related to risk management - plays an important role for the banks, because it enables the managing bodies to "authorize, optimize and monitor risk taking in an enterprise" (Peddada, 2014). Risk oversight has to be ensured by the whole board, but the operational responsibility has the Chief Risk Officer (CRO). The integration of the CRO in the organizational structure varies in the different institutions. Mikes (2009) adopts four different risk management types: compliance champion, modelling expert, strategic advisor, and strategic controller. Furthermore, the use of risk committees is an important part of the governance set-up (Peddada, 2014).

Afanasyeva, Lapina, and Scherbina (2013) find that adding the installation of a Risk Management Committee has also positive effects on the firm performance. Apart from the influence of the CRO in a financial institution, Kirkpatrick (2010) also highlights that risk management practices in many banks were not sufficiently developed before the crisis. In this article, analyzing risk management techniques is not in scope, but the fact that board members and other responsible committee members were not informed about the shortcomings and the upcoming problems is a corporate governance issue. Kirkpatrick (2010) provides evidence that in many banks, the personnel attributed to make management decisions and oversee the banks' control systems was informed too late about changed market conditions and problems in the companies' performance. After the crisis regulators put high attention to increase the banks' risk management. The chosen approaches comprise, on the one hand, increasing the legal requirements with respect to risk management practices also considering a forward-looking approach with e.g. stress testing and, on the other hand, strictly observing compliance with the rules through supervision. A major part that the supervisory framework emphasizes is risk governance.

\subsection{Boards}

With regard to board composition of banks, aspects such as number, busyness and age of board members, CEO duality, etc. are investigated. Firstly, for CEO duality, i.e. that CEO holds also the position of the chairperson of the board, it was found as having a negative effect on firm performance during the crisis situation (Grove, Patelli, Victoravich, \& Xu, 2011). Kirkpatrick (2010) raises the issue of performance of board members as part of the reasons for the negative impact on firm performance during the crisis. For suitability of board members, some examples are mentioned in the area of corporate governance. First, the existence, frequency and seriousness of committees like the risk or audit committee was under the influence of the board members. Second, all board members have to take risk management seriously and should be up-to-date with respect to new regulations and techniques. This was not always the case as risk management was considered as "too specialist for meaningful oversight by the whole board". Kirkpatrick (2010) admits that measuring board member's competence is very difficult. The fit and proper assessments which are part of the new regulatory and supervisory regime in the European Banking Union are a mechanism to make sure that board members and other key managers have a suitable background and experience. This does not only apply for executive board members, but also for non-executive board members. The Chartered Institute of Management Accountants (CIMA, 2012) found room for improvement for the non-executive board regarding the formalization of the recruitment process, the independency and the range of selection criteria. Another highly important finding addresses the lack of challenging capacity of non-executive board members and supervisory board members in a two-tier board structure, respectively. The term challenging capacity refers to the objective of the non-executive board members to check decisions, 
raise questions and maybe also express disagreement on certain topics. Apart from expertise, non-executive directors have to show sufficient time commitment for fulfilling their duty.

\subsection{Compensation}

Another aspect which has been investigated very intensively after the financial crisis is executive compensation and its impact on firm performance during the crisis. The reason for the interest in this topic is that excessive risk taking caused by wrong remuneration incentive systems is blamed as one of the main reasons for the financial crisis from the corporate governance perspective. In the 1990s, famous scholars found that it is important to align executives' and shareholders' interest to increase firm performance. Holmström and Tirole (1993) developed a model that shows that the best incentive for CEOs to be conformed to shareholders' goals is to reward them with stock-based compensation. Becht, Bolton, and Röell (2012) confirm that this opinion gained acceptance during the past two decades and that as a consequence the stock price of a company has been approved as a benchmark for CEO performance. Fahlenbracht and Stulz (2011) provide evidence that the concept of alignment of shareholders' and CEOs' interest did not sustain in the financial crisis. Based on their research they found no evidence that better aligned CEOs performed better during the crisis. They even go one step further by arguing that shareholder-CEO alignment was a reason for worse performance. The evolution of research outlined in this article can be summarized as follows: It was seen beneficial for firm performance to align CEOs' interest with the shareholders' one. The best way to achieve this is to provide incentives in terms of performance pay with stock. As a consequence, this kind of incentive resulted in excessive risk taking by the CEOs which was in line with shareholders' interest. But during the crisis, the higher risk turned out to be not beneficial showing higher losses for companies with higher CEO and shareholder alignment. Hüttenbrink, Kaserer, and Rapp (2014) analyze the correlation between financial regulation and incentives for the management of banks and find that shareholders tend to offer higher incentives in countries where regulation tends to be stricter.
The examples show that bank governance is different and more complex than for non-financial companies. Becht, Bolton, and Röell (2012) give one of the most important examples for why bank governance is different. Banks' business models are designed for taking and managing risk. It is undisputed that also non-financial companies face several risks in their course of business, but the big differences are, on the one hand, the systemic importance that lies in the nature of banking and, on the other hand, that the risk does not only have an impact on shareholders, but also on other stakeholders, such as, for example, depositors, creditors, counterparties and as the financial crisis has shown also taxpayers.

Haan and Vlahu (2013) underline that in general corporate governance academic papers, the assessment of financial firms is often left aside. Another aspect which increases the complexity of corporate governance in banks is the "too-big-to-fail" commitment of governments and policy makers (Haan \& Vlahu, 2013). Especially for big banks it is unlikely that governments let them break due to their systemically important role, which can be an incentive for banks to take higher risk.

Regulators are another stakeholder which has to be taken into account when discussing corporate governance topics in banks. Regulators have a serious effect on internal governance practice. As banks are highly regulated and supervised these days, corporate governance practice differs immensely between financial and non-financial firms because of the regulatory influence (Haan \& Vlahu, 2013).

The next difference pointed out by Haan and Vlahu (2013) refers to ownership concentration. In corporate governance theory, concentrated ownership correlates with better monitoring and control, because the more stock one shareholder holds the more incentives it has to take care about the company well-being. Large shareholders are more interested to be informed about the company's business and make better use of the voting rights. It is stated that, mostly in the US, the likelihood of large shareholders is higher in financial firms than in non-financial firms. In Europe, differences exist between UK and continental Europe with respect to ownership concentration. While in continental 
Europe ownership is concentrated in the UK, the share of the largest block holding is much lower on average (Köhler, 2009). Concentrated ownership has the advantage that the management's and large shareholders' interests can be better aligned. However, another agency problem can occur between large and minority shareholders.

With respect to compensation, the following difference is highlighted apart from the previously mentioned aspect of alignment of the executives' and the shareholders' interest. Whereas it is more common for executives in non-financial firms to lead the company through reorganizations in times of financial distress, it is often the case that in financial firms the executive management is exchanged in negative times (Haan \& Vlahu, 2013).

Furthermore, general corporate governance literature usually refers to the concept of market for corporate control, which is based on the assumption that the threat of hostile takeovers disciplines the executives of a company to increase firm performance. The theory suggests that executives are afraid of being substituted by the acquirers. Hence, as it is mentioned the market for corporate control plays no role in banks' corporate governance (Haan \& Vlahu, 2013).

\section{IMPLICATIONS}

So the question is if stricter regulation in terms of the SSM can improve corporate governance in the European banking sector? It was often and explicitly stated by regulatory as well as supervisory representatives that weak corporate governance was playing a big part in the emergence of the recent financial crisis. For this reason, one of the first reactions to the weaknesses in bank governance from a European regulatory point of view, the CRR and CRD IV were precedent-setting. Articles 88-96 of the final CRD IV version of June 26, 2013 (see Table 1) build the corner stones of ECB's corporate governance framework. Whereas Article 88 outlines the general requirements regarding internal governance, Article 91 refers to the suitability of the management body, and Articles 92-95 set out rules for remuneration. The other mentioned articles contain expectations concerning public disclosure.

Mehran, Morrison, and Shapiro (2011) describe the relation between supervisors and bank's corporate governance as difficult, because "there are no hard and fast rules, and just when a practice becomes widely accepted as best practice, exceptions of the rules emerge in precisely those firms most in need of good governance". Furthermore, they point out that the priority of regulators and supervisors should be to bring awareness of safety and soundness into the banks' board rooms. Engagement, expertise and independence are mentioned as the key principles of board members best practice with respect to governance. In addition, supervision shall investigate and increase the challenging capacity of the executive board members to challenge the management as well as the supervisory board to challenge the decisions and actions of executives. All of these elements are part of EC's Guide to fit and proper assessment, which will be discussed in the next part of the present paper. Mehran, Morrison, and Shapiro (2011) raise a point that is crucial for the whole function-

Table 1. CRD IV - Articles related to governance topics

Source: Own illustration, CRD IV.

\begin{tabular}{|c|c|c|}
\hline Article & Title & EBA Guidelines \\
\hline Article 88 & Governance arrangements & EBA Guidelines on Internal Governance \\
\hline Article 89 & Country-by-country reporting & - \\
\hline Article 90 & Public disclosure of return on assets & - \\
\hline Article 91 & Management body & $\begin{array}{l}\text { Joint ESMA and EBA Guidelines on the assessment } \\
\text { of the suitability of members of the management } \\
\text { body and key function holders; } \\
\text { ECB Guide to fit and proper assessments }\end{array}$ \\
\hline Article 92 & Remuneration policies & \multirow{4}{*}{ EBA Guidelines on sound remuneration policies } \\
\hline Article 93 & Institutions that benefit from government intervention & \\
\hline Article 94 & Variable elements of remuneration & \\
\hline Article 95 & Remuneration Committee & \\
\hline Article 96 & $\begin{array}{l}\text { Maintenance of a website on corporate governance and } \\
\text { remuneration }\end{array}$ & - \\
\hline
\end{tabular}


ing of the framework of bank governance and its dependence on regulation and supervision: Whereas the board may feel only responsible for acting in the interest of shareholders, the authorities have the objective to add other stakeholders like creditors, depositors and taxpayers to the board's consideration.

Dermine (2011) presents a slightly different view on this topic by proposing a separation of accountability between the board, who guarantees shareholder's value maximization, and the supervisory authorities, who shall defend the safety and soundness of the banking system. The interest of the other stakeholders is automatically defended, when the banks are forced by the rule makers to act according to a safe and sound banking environment.

If banking supervision should play an increasingly important role, it has to be considered that supervisors have to be more integrated into the (internal) governance systems of banks. Arndorfer and Minto (2015) provide an approach to further supervisory integration into banking systems by establishing the 'four lines of defence' model of financial institutions, which is a development of the common 'three lines of defence' model.

One of the requirements set in the SREP Guidelines with regard to internal governance refers to the organization and functioning of the management body. The ECB has also published a guide to fit and proper assessment (ECB Banking Supervision, 2017d).

The interaction between the EBA Guidelines and the ECB guide was outlined in a public consultation (ECB - Banking Supervision, 2017c) following the draft version of the guide to fit and proper assessment (ECB - Banking Supervision, 2016b). Whereas the EBA provides the regulatory basis in the single rulebook, the ECB tries to transpose the rules into practice with this guide and express their stance on the interpretation. But, the practical implementation can also give input for regulation in the other way around. Nevertheless, ECB's intention of the guide to fit and proper assessments is to ensure compliance with the legal framework across the participating member states. As a consequence, the ECB guide is more detailed, explains the process which has to be followed and gives an indication on which type of information is needed by the ECB to conduct fit and proper assessments.

It is undisputed that the quality of the top management in the banks contributes to the safety and soundness of the banking sector. It was one of the claims resulting from the recent financial crisis that some of those responsible in the banking institutions were not able to adequately conduct all necessary tasks for a proper management of their banks. ECB in its supervisory role puts high requirements on the suitability of the supervised banks, especially on the significant institutions. As regulated in the SSM Regulation under Article 6 para. 4, fit and proper assessments in less significant institutions are fully under responsibility of national competent authorities (ECB - Banking Supervision, 2016c).

Article 91 CRD IV provides the legal basis for the fit and proper powers of the ECB. As the CRD IV is a directive, which had to be transposed to national law, the fit and proper regulation is not uniform in all 19 Euro area countries. ECB's guide to fit and proper assessments, as well as the related EBA guidelines, seek to harmonize the rules and have the aim to increase consistency in practice. Furthermore, it is stipulated in Article 4 para. 1 that ECB has the assignment to conduct the task of fit and proper assessments (ECB - Banking Supervision, 2017d).

The process of fit and proper assessments is depicted in Figure 3 from an operational point of view. In general cases, the supervised entity has to notify the appointment of changes in the management body and of key function holders. For significant institutions, it is foreseen that the notification is provided to the NCAs in the usual national form. The NCA informs ECB about the notification and fulfills all further data gathering and assessment tasks in collaboration with ECB. The responsibility of the final decision relies on the Supervisory Board of the ECB and the Governing Council based on the proposal of the ECB and NCA.

Regarding compensation, excessive risk taking incentivized by unreasonable remuneration arrange- 


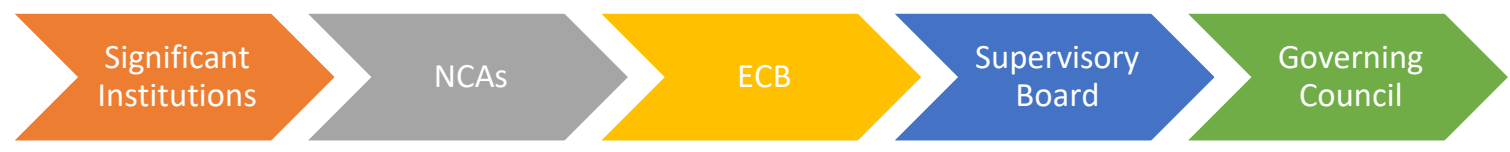

Figure 3. Stakeholders involved in fit and proper assessments

ments in banks was identified as the main reason for the recent financial crisis. In summary, the newly introduced concepts in these guidelines concern the relation of fixed and variable compensation. This ratio is limited to $100 \%$ in general and in case of shareholders' approval to $200 \%$. Further aspects are stricter requirements regarding malus and clawback as well as requirements regarding the type of instruments used for buying out the variable part of remuneration (EBA, 2016).

\section{CONCLUSION}

As one can see, a perceived overshooting of the newly imposed requirements since the publishing of the Basel III rules is a further highly recurrent criticism. Inevitably, there is a conflict between high regulation to reduce risk, but leading to high capital costs, and the expectations to adopt the business models to increase efficiency. A further complicating point for banks' profitability is the currently pursued low-interest monetary policy. All in all, it can be said that on the cost side the burden to comply with regulatory requirements are challenging managers in the banking sector, whereas the low interest rate environment is impeding banks' profitability on the revenue side. On the contrary, there are also voices which claim that the actual level of banking regulation does not go far enough. Admati and Hellwig (2013) stipulate that the share of equity has to be much higher as it is currently required by banking regulation. A uniform leverage ratio of at least 20 to $30 \%$ for all banks is proposed by them. In return, the financial burden caused by comprehensive risk calculation - e.g. through internal models - disappears, because in this concept no difference is made between banks with respect to the impact of the risk situation on the required capital ratio. Admati and Hellwig's work was controversially discussed and picked to pieces in the recent years. Also a representative of the ECB joined the discussion and clearly stated that uniformity of capital requirements is not the key solution, but that there is an individual optimal level for each bank which depends on measurement of risks (ECB - Banking Supervision, 2017e). Of course, it has to be ensured that the calculation of capital requirements with the use of internal models is adequate and reliable. This is the reason why ECB puts its focus on assessing risk modelling in its Targeted Review on Internal Models.

With respect to the goal of a level playing field for banks it can be claimed that the intention to accomplish this target is seen for banking regulation, but is missing for other related fields, e.g. taxation. Bénassy-Quéré, Trannoy, and Wolff (2014) argue that a unified corporate tax shall be paid by all significant banks in the SSM on the European level. In application of the goal of harmonization, a uniform tax rate would have to be applied as a consequence.

In terms of corporate governance, a dangerous aspect of the harmonization ambitions of the regulators is raised by Binder (2015). The objectives of the European Banking Union are, on the one hand, defining best practice and promoting consistency and, on the other hand, to consider the proportionality principle with regard to the diversity in the market structures and business models. The intuitive perception of these goals is that they seem to be conflicting. Over the course of time, it can happen that the ECB's intention of convergence will lead to more unified and streamlined business models and governance schemes in supervised banks. The discussion regarding the revision of the 
Basel III framework indicates this perception. The possibility of calculating regulatory capital requirements with internal models could be reduced by applying more standardized approaches or floors (Magnus, Duvillet-Margerit, \& Mesnard, 2017).

Apart from the addressed disagreement regarding the bonus cap in the field of regulation of remuneration and the need of refinements for the Guidelines on Internal Governance and regarding fit and proper assessment, the general opinion about the European corporate governance framework, as outlined in this article, is quite positive. Richter (2014) supports this opinion by concluding his paper with the statement that the adaptions in the field of risk governance "can be seen as positive". At the same time, he brings the issue of proportionality on the table. However, the competent authorities seem to have understood this general recurring topic of criticism and refer to this point in several discussions during consultation phases and revise some guidelines with more focus on the proportionality principle. Regarding the remuneration principles in the CRD IV, respective EBA guidelines and respective supervisory oversight, it is stated that their impact on risk management can be seen as significant. As the linking of remuneration regulation to risk governance was a main goal, it can be viewed as successful in this first review. The practice regarding transparency is a field where room for improvement is noted in this study. It will be very important that the involved agencies better cooperate when drafting new regulations, technical standards, guidelines, etc. At the current set-up too many stakeholders are involved in the processes regarding the definition of the regulatory framework for the European banking sector. There are discussions on the international level regarding an update of Basel III and at the same time European legislators decide on a revision of the CRR/CRD IV package. It should be possible to react faster to detected weaknesses in the regulatory framework and to adopt improved rules more efficiently than in the current set-up. This kind of two-track issue is also observed in connection with the guidelines setting approach in the European banking industry. EBA and ECB, both are issuing guidelines stating their opinion on certain topics. In case of the guides concerning Fit and Proper assessment, it is noticeable that the proceeding of both authorities seems to be not coordinated neither in terms of content nor in terms of timing. A further issue which is also connected to the regulatory practice concerns the stability of regulation. It is also important that the regulatory environment in the banking sector remains stable in the upcoming years, so that the banks and the supervisory authorities can adopt and define best practices in all related fields. A new wave of deregulation, which was brought to the table in the US, would make most of the efforts of the past years obsolete. But currently, it can be assumed that the envisaged new policy changes do not include the intention to weaken the corporate governance regulations in the US (McLucas \& Murphy, 2017).

This study can build the basis for future work in this field, for example, for the analysis of the development of key performance indicators over time. In the future, it would also be important for the European Central Bank to establish profound considerations with academic background in order to support their practical views by theoretical evaluations in a consistent manner. Hopt (2013) raises a similar issue by claiming that regulatory activities and academic research should be far more interconnected. Another topic which is very much under public attention at the moment is the sector of financial technologies (FinTech). The consideration by regulators and supervisors are currently at an early stage in this field, so are the governance requirements for those firms. It is the objective of the regulatory bodies to make sure that the dealing with every relevant risk in the financial sector - irrelevant if originated in traditional banks or FinTechs - is regulated (Dombret, 2016). But the question is if this trend towards digitalization cannot be utilized for governance processes as well. Regulatory technologies (RegTech) seem to appear and develop in a comparable manner as FinTechs. RegTech have the potential to promote innovation, improve the data quality for regulatory reports and reduce compliance costs with regulatory requirements (EY, 2016). All of these benefits can be incorporated and coupled with existing governance arrangements. Thus, emerging new types of IT and outsourcing risks have to be adequately considered in the governance framework. Much more analysis in this field also in academic research is essential for enhancing efficiency and safety in the banking sector. 


\section{REFERENCES}

1. Admati, A., \& Hellwig, M. (2013). The Bankers' New Clothes: What's Wrong with Banking and What to Do about It. Princeton University Press.

2. Afanasyeva, O., Lapina, Y., \& Scherbina, T. (2013). Risk Management, Corporate Governance and Investment Banking: The Role of Chief Risk Officer. Corporate Ownership \& Control, 10(3), 312-330.

3. Arndorfer, I., \& Minto, A. (2015). The "four lines of defence model" for financial institutions. BIS Bank for International Settlement, Paper 11.

4. Becht, M., Bolton, P., \& Röell, A. (2012). Why bank governance is different. Oxford Review of Economic Policy, 27(3), 437-463.

5. Beck, T. (2015). Europe’s banking union: glass half full or glass half empty? In E. Nowotny, D. Ritzberger-Grünwald, \& H. Schuberth (Eds.). The Challenge of Rebalancing in Europe. Österreichische Nationalbank, Edward Elgar, Cheltenham.

6. Bénassy-Quéré, A., Trannoy, A., \& Wolff, G. (2014). Tax Harmonization in Europe: Moving Forward. Notes du conseil danalyse économique, 14(4).

7. Binder, J.-H. (2015). Banking Union and the Governance of Credit Institutions - A Legal Perspective (SAFE Working Paper 96).

8. Breuss, F. (2013). European Banking Union (WIFO Working Papers 454).

9. Breuss, F., Roeger, W., \& in't Veld, J. (2015). The stabilising properties of a European Banking Union in case of financial shocks in the Euro Area (Economic Papers 550. European Commission).

10. Bullard, J., Neely, C. J., \& Wheelock, D. C. (2009, Sept./Oct.). Systemic Risk and the Financial Crisis: A Primer. Federal Reserve Bank of St. Louis Review, 1, 403-418.

11. Cao, J. (2014). Banking Regulation: Theory and Practice. Norges Bank Research. Retrieved from http:// www.uio.no/studier/emner/sv/
oekonomi/ECON4335/h14/uio_lecture_regulation(1).pdf

12. Cerutti, E., Claessens, S., \& McGuire P. (2012). Systemic Risks in Global Banking: What Can Available Data Tell Us and What More Data Are Needed? (BIS Working Papers 376. Bank for International Settlements).

13. Chartered Institute of Management Accountants - CIMA (2012). NonExecutive Directors: Their Value in Management. Retrieved from http:// www.axiom-e.co.uk/pix/ned-value. pdf

14. Davis, E. P., \& Obasi, U. (2009). The Effectiveness of Banking Supervision (Brunel University, Economics and Finance Working Paper Series 09-27).

15. De Groen, W. P., \& Lannoo, K. (2014). The ECB AQR and the EBA Stress Test: What will the numbers tell? CEPS Commentary.

16. Dermine, J. (2011). Bank Corporate Governance, Beyond the Global Banking Crisis (INSEAD Working paper).

17. Deutsche Bundesbank (2016). The supervision of less significant institutions in the Single Supervisory Mechanism (Monthly Report 51, January 2016).

18. Dombret, A. R. (2016). Beyond technology - Adequate regulation and oversight in the age of fintechs. In Banque de France, Financial Stability in the Digital Era. Financial Stability Review 20.

19. Dragomir, L. (2010). European Prudential Banking Regulation and Supervision: The Legal Dimension. Routledge.

20. EBA (2016). 2016 EU-Wide Stress Test Results. European Banking Authority.

21. EC - European Commission (2014). Banking union: restoring financial stability in the Eurozone. MEMO/14/294.

22. ECB - Banking Supervision (2014). Guide to banking supervision. European Central Bank.

23. ECB - Banking Supervision (2016a). ECB Annual Report on supervisory activities 2015 .
24. ECB - Banking Supervision (2016b). Draft guide to fit and proper assessments. November 2016

25. ECB - Banking Supervision (2016c). ECB launches consultation on guide to assessments of board members. Press Release. Retrieved from https://www.bankingsupervision. europa.eu/press/pr/date/2016/html/ sr161114.en.html

26. ECB - Banking Supervision (2017a). List of supervised entities. Retrieved from https://www.bankingsupervision.europa.eu/ecb/pub/pdf/ list_of_supervised_entities_201701. en.pdf?fa67031bce20d0ce07da37a4 c0685435

27. ECB - Banking Supervision (2017b). ECB Annual Report on supervisory activities 2016.

28. ECB - Banking Supervision (2017c). Public consultation on the draft ECB guide to fit and proper assessments Questions and answers. Retrieved from https://www.bankingsupervision.europa.eu/legalframework/ publiccons/pdf/fap/fap_qa.en.pdf

29. ECB - Banking Supervision (2017d). Guide to fit and proper assessment. Final Version, May 2017.

30. ECB - Banking Supervision (2017e). Risk and capital - a balancing act. Speech by Danièle Nouy, Chair of the Supervisory Board of the ECB, at the Austrian Chamber of Commerce, Vienna, May 2, 2017. Retrieved from https://www. bankingsupervision.europa.eu/ press/speeches/date/2017/html/ssm. sp170502.en.htm

31. ECB (2014). Aggregate Report on the Comprehensive Assessment. European Central Bank.

32. ECB (2016). Stress test shows increased resilience of euro area banking system. Press release 29/07/2016

33. Eken, M. H., Kale, \& S., Selimler, H. (2013). The Evolution of Regulations in Banking: A Cycle Based Approach. ACRN Journal of Finance and Risk Perspectives, 2(2), 15-26.

34. Eubanks, W. W. (2010). The European Union's Response to 
the 2007-2009 Financial Crisis. Congressional Research Service.

35. EY (2016). Innovating with RegTech: Turning regulatory compliance into a competitive advantage. Retrieved from http://www.ey.com/Publication/vwLUAssets/EY-Innovatingwith-RegTech/\$FILE/EY-Innovating-with-RegTech.pdf

36. Fahlenbracht, \& Stulz (2011). Bank CEO Incentives and the Credit Crisis. Journal of Financial Economics, 99(1), 11-26.

37. Freixas, X., \& Santomero, A. M. (2003). An Overall Perspective on Banking Regulation (UPF, Economics and Business Working Paper 664).

38. Galati, G., \& Moessner, R. (2011). Macroprudential Policy - a literature review (BIS Working Paper No. 337. Bank for International Settlements).

39. Grove, H., Patelli, L., Vitoravich, L. M., \& Xu, P. (2011). Corporate Governance and Performance in the Wake of the Financial Crisis: Evidence from US Commercial Banks. Corporate Governance: An International Review, 19(5), 418-436.

40. Haan, J., \& Vlahu, R. (2013). Corporate Governance of Banks: A Survey (DNB Working Paper, 386).

41. Hafeman, M., \& Randle, T. (2009). On and Offsite Inspections. Primer Series on Insurance, 13, World Bank.

42. Hodson, D., \& Quaglia, L. (2009). European Perspectives on the Global Financial Crisis: Introduction. Journal of Common Market Studies, 47(5), 939-953.

43. Holmström, B., \& Tirole, J. (1993). Market Liquidity and Performance Monitoring. The Journal of Political Economy, 101(4), 678-709.

44. Hopt, K. J. (2013). Better Governance of Financial Institutions (Law Working Paper, 207).

45. Hüttenbrink, A., Kaserer, C., \& Rapp, M. S. (2014). Regulation, Compensation and Risk Taking in Banks: Evidence from the Credit Crises (EFMA Working paper).

46. Kirkpatrick, G. (2010). The Corporate Governance Lessons from the Financial Crisis. In United Nations, Corporate Governance in the Wake of the Financial Crisis
Selected International Views. New

York and Geneva.

47. Köhler, M. (2009). Blockholdings and Corporate Governance in the EU Banking Sector (ZEW Discussion Paper, 08-110).

48. Kosior, A., \& Rubaszek, M. (2015). The economic challenges of Poland's integration with the euro area. Translation. Naradowy Bank Polski.

49. Magnus, M., Duvillet-Margerit, A., \& Mesnard, B. (2017). Upgrading the Basel standards: from Basel III to Basel IV? (Briefing Paper, European Parliament).

50. Majone, G. (1996). Regulating Europe. Routledge.

51. McLucas, W. R., \& Murphy, R. (2017). Corporate Governance in The Trump Era: A Note of Caution. Westlaw Journal, 32(21). Retrieved from https://www.wilmerhale. com/uploadedFiles/Shared_Content/Editorial/Publications/ Documents/2017-05-04-CorporateGovernance-in-The-Trump-EraA-Note-of-Caution.pdf

52. Mehran, H., Morrison, A., \& Shapiro, J. (2011). Corporate Governance and Banks: What Have We Learned from the Financial Crisis? (Federal Reserve Bank of New York Staff Reports, 502).

53. Mikes, A. (2009). Risk Management and Calculative Cultures. Management Accounting Research, $20,18-40$.

54. Mishkin, F. S. (2001). Prudential Supervision. Why Is It Important and What Are the Issues? In F. S. Mishkin, Prudential Supervision. What Works and What Doesn't (NBER Conference Report). The University of Chicago Press.

55. OeNB - Austrian National Bank (2017a). Banking Union. Retrieved from https://www.oenb.at/en/Publications/Oesterreichische-Nationalbank/Annual-Report.html

56. Ogus, A. (2009). Regulation Revisited. Sweet and Maxwell, reprinted from Public Law Issue, 2, 332-346.

57. Peddada, K. (2014). Risk Assessment and Control. In A. N. Kostyuk, O. Afanasyeva, \& Y. Mozghovyi (Eds.), Governance
\& Control in Finance \& Banking: A New Paradigm for Risk \& Performance (pp. 95-112). Scholar's press, Saarbrücken.

58. Penikas, H. (2015). History of Banking Regulation as Developed by the Basel Committee on Banking Supervision in 1974-2014 (Brief Overview). National Stability Journal of the Bank of Spain, 28, 9-48.

59. Pichet, E. (2014). Building on Foundations for a New Central Bank Doctrine: Redefining Central Banks' Missions in the 21st Century. In A. N. Kostyuk, O. Afanasyeva, \& Y. Mozghovyi (Eds.), Governance \& Control in Finance \& Banking: A New Paradigm for Risk \& Performance (pp. 113-141). Scholar's press, Saarbrücken.

60. Richter, T. (2014). Risk Governance als Kooperationsproblem in der Unternehmensführung von Banken. Heinrich Heine Universität Düsseldorf.

61. Santos, J. A. C. (2000). Bank Capital Regulation in Contemporary Banking Theory: A Review of Literature (Bank for International Settlements - BIS Working Papers, 90).

62. Schoenmaker, D. (2015). Firmer Foundations for a Stronger European Banking Union (Bruegel Working Paper, 13).

63. SRB (2015). Work Programme 2016. Single Resolution Board.

64. SRB (2016). The Single Resolution Mechanism Introduction to Resolution Planning. Single Resolution Board.

65. Tröger, T. H. (2013). The Single Supervisory Mechanism -Panacea or Quack Banking Regulation? (Working Paper Series 73, Institute for Monetary and Financial Stability).

66. Wruuk, P. (2015). Deposit insurance in the Banking Union: Options for the third pillar. Deutsche Bank Research Briefing. 